\title{
FAKTOR DAN UPAYA RESOLUSI KONFLIK SOSIAL (Kasus Kelurahan Kandai Dua Kecamatan Woja Kabupaten Dompu)
}

\author{
Jayusman 1, Syarifuddin, Khalifatul Syuhada \\ Universitas Mataram
}

\begin{abstract}
Conflict between citizens of this village is because it is caused by several factors, one of which is juvenile delinquency. Juvenile delinquency is a pathological symptom of teenagers arising from the form of social neglect ultimately causing behavior that can harm oneself or others. The problems studied in this research are: first, the factors that triggered the occurrence of social conflict in the sub district Woja Dompu? Second, social conflict resolution efforts in the sub district Woja Dompu? The research aims to determine the factors that triggered the social conflict in the sub district Woja Dompu, and the social conflict resolution efforts in the sub district Woja Dompu. The method used in research is a qualitative method. The data collection methods used are interviews and documentation. The validity of the data is tested by triangulation technique, which is then analyzed through reduction, data presentation, withdrawal of conclusions. The results of the research showed that social conflicts in the sub District Woja Dompu in the presence of influence of several factors: juvenile delinquency, revenge, weak law, and differences of interest. The efforts of social conflict resolution in Woja subdistrict to dampen the conflict between the citizens of Kandai Dua and the residents of Simpasai village, by negotiation, conduation, mediation, and arbitration. Local governments work with communities to form vigilance organisations as a step in minimizing social conflicts
\end{abstract}

Keywords : Factors, Attempts, Conflict Resolution.

\begin{abstract}
Abstrak
Konflik antar warga kelurahan ini adalah karena disebabkan oleh beberapa faktor salah satunya adalah kenakalan remaja. Kenakalan remaja merupakan gejalah patologis pada remaja yang muncul akibat dari bentuk pengabaian sosial pada akhirnya menyebabkan perilaku yang dapat merugikan diri sendiri maupun pihak lain. Permasalahan yang dikaji dalam penelitian ini adalah: pertama, faktor-faktor apa yang memicu terjadinya konflik sosial di Kecamatan Woja Kabupaten Dompu? Kedua, upaya resolusi konflik di masyarakat Kecamatan Woja Kabupaten Dompu? Penelitian ini bertujuan untuk mengetahui faktorfaktor yang memicu terjadinya konflik sosial di Kecamatan Woja Kabupaten Dompu, dan upaya resolusi konflik sosial di Kecamatan Woja Kabupaten Dompu. Metode yang digunakan dalam penelitian adalah metode kualitatif. Metode pengumpulan data yang digunakan yaitu wawancara dan dokumentasi. Keabsahan data diuji dengan teknik triangulasi, yang kemudian dianalisis melalui reduksi, penyajian data, penarikan kesimpulan. Hasil penelitian yang diperoleh menunjukkan bahwa konflik sosial di kecamatan woja kabupaten dompu disebabklan adanya pengaruh beberapa faktor: kenakalan remaja, dendam, hakum yang lemah, dan perbedaan kepentingan. Upaya resolusi konflik sosial di Kecamatan Woja untuk meredam konflik yang terjadi antara warga Kandai Dua dengan
\end{abstract}

\footnotetext{
${ }^{1}$ Jayusm046@gmail.com
} 
warga Simpasai dialukan dengan cara negosiasi, konsilisasi, mediasi, dan arbitrasi. Pemerintah daerah bekerja sama dengan masyarakat membentuk organisasi kewaspadaan sebagai langkah meminimalisir konflik sosial.

Kata Kunci : Faktor, Upaya, Resolusi Konflik

\section{Pendahuluan}

Nusa Tenggara Barat (NTB) merupakan salah satu Provinsi, yang terdapat di Kawasan Indonesia Timur, terdiri dari delapan Kabupaten dan dua kota madia yang berada pada dua pulau besar, yakni Lombok dan Sumbawa sehingga memiliki penduduk yang heterogen. Berbagai etnis/suku tinggal di NTB, adapun etnis/suku mayoritas adalah Sasak, Samawa, dan Mbojo. Di Provinsi NTB juga terdapat berbagai etnis/suku lain diluar suku asli yakni; Bali, Jawa ,Minang, Sunda Madura, Flores, Melayu, Bugis, Bajo, Tionghoa, Arab yang tersebar di seluruh wilayah Nusa Tenggara Barat.

Etnis/suku Mbojo, yang merupakan penduduk asli di Kabupaten Dompu dan Bima (di Pulau Sumbawa), lebih dekat kekerabatannya dengan kelompok etnis yang terdapat di Sumba, Flores, Makasar atau yang dikenal dengan istilah subkeluarga Austronesia Timur, sedangkan dua etnis lainnya: etnis Sasak dan etnis Samawa (menghuni pulau Lombok dan menghuni pulau Sumbawa bagian Barat) memiliki hubungan kekerabatan yang lebih dekat, yaitu berasal dari Proto-SasakSumbawa atau dalam kelompok yang lebih besar, bersama Bali, Jawa dan lain-lain masuk pada subkeluarga Autronesia Barat(prof-mahsun.com).

Masyarakat yang memiliki heterogenitas atau perbedaan cenderung terjadi konflik sosial. Konflik sosial yang muncul di masyarakatk khususnya NTB mulai mencuat sejak tumbangnya rezim orde baru pada tahun 1998 dan berlangsung hingga sekarang. Permasalahan yang muncul hampir sama dengan daerah lain di Indonesia yakni; rasial, agama hingga politik dan ekonomi. Beragamnya suku dan agama yang ada di Nusa Tenggara Barat berimplikasi pada intensitas terjadinya konflik sosial vertical maupun horisontal, terbuka maupun tertutup. Dari berbagai konflik yang muncuat tersebut, NTB dikenal sebagai daerah rawan konflik sosial, 
hingga dinyatakan berada pada Zona Merah Konflik. Sebagaimana dilansir oleh berbagai media bahwa Nusa Tenggara Barat pada tahun 2017, dinyatakan bebas dari Zona Merah konflik sosial (REPUBLIKA.co.id). Akan tetapi walaupun dengan dinyatakan terbebas dari "Zona Merah Konflik" konflik sosial masih muncuat diberbagai daerah. Hal ini tercemin dari mencuatnya kasus konflik di berbagai daerah Provinsi Nusa Tenggara Barat.

Sebagaimana di Pulau Lombok merupakan salah satu daerah di NTB seringkali mencuat konflik sosial. Adapun konflik yang terjadi adalah konflik antar agama, antar organisasi keagamaman, antar kampung. Sebagaimana yang dilansir oleh media pada tahun 2006 terjadi konflik keyakinan antar organisasi Salafi. Masyarakat menolak keberadaan sekaligus penyelenggaraan kegiatan keagaman oleh Salafi (liputan6.com). Disisi lain keberadaan Ahmadiyah pada 2006 menuai pertikaian dengan masyarakat mengenai keberadaan dan eksisitensi ahmadiayah. Konflik yang baru-baru mencuat adalah yang terjadi antar kampung Monjok dan Taliwang pada tahun 2017, sedangkan pada 2018 masyarakat dengan Jamaah Ahmadiah di Lombok Timur (suarantb.com).

Sementara itu, di Sumbawa konflik sosial serupa juga pernah terjadi. Hal ini, karena perbedaan budaya dan suku yang dipicu oleh perbagai permasalahan kecil bahkan kesalahpahaman hingga meledak menjadi konflik besar. Sebagaimana yang terjadi pada tahun 2012 berlanjut hingga 2013 dan menyebabkan 500 warga diungsikan (TEMPO.CO).

Sedangkan di Bima, konflik yang terjadi adalah konflik vertikal dan horisontal. Konflik vertikal yang terjadi antar pemerintah, swasta dengan masyarakat karena adanya perbedaan kepentingan, misalnya alih fungsi lahan untuk pembangunan dan tambang. Sebagaimana yang pernah terjadi di Kabupaten Bima di Lambu Sape dan Parado terjadi pada 2011. Konflik antar desa dalam satu Kecamatan Woha yakni; Desa Risa dan Dadibou terjadi pada tahun 2017. Hal serupa juga terjadi di Dompu, konflik horizontal mencuat di masyarakat pada tahun 2012 hingga 2014 Konflik dipicu oleh perbedaan kepentingan individu dan kelompok dan motif sosial lain. Pada tahun 2016 konflik antar warga desa sesama 
Kecamatan juga sering kali terjadi yakni desa Ta'a dan Soro dan kelurahan Kandai Dua dengan Simpai (Tempo.CO).

Penelitian ini memfokuskan pada konflik sosial yang terjadi di daerah Dompu (pulau Sumbawa) khususnya Kecamatan Woja. Kecamatan Woja merupakan salah satu Kecamatan yang rawan terjadinya konflik. Beberapa wilayah dengan intesitas konflik yang cukup sering terjadi adalah Kelurahan Kandai Dua dengan Kelurahan Simpasai. Sebagaimana pada tahun 2012 lalu konflik antar warga Kelurahan Kandai Dua dengan Kelurahan Simpasai mengusik ketenangan Kabupaten Dompu. Sejumlah korban pun berjatuhan dari kedua belah pihak. Kenyamanan masyarakat terganggu karena sejumlah titik jalan diblokir (bimakini.com). Pemicu dari konflik yang pernah terjadi adalah dendam lama yang akhirnya kembali muncul. Permusuhan lama di tambah lagi dengan beberapa oknum tertentu dari kedua kelurahan saling memprovokasi yang dilakulan oleh sekelompok preman (Liputan6.com, Dompu).

Sebagaimana dikutip dari media bahwa konflik pun tidak dapat terhindarkan, konflik yang diwarnai dengan aksi lempar batu diperbatasan kelurahan Kandai Dua dengan perbatasan kelurahan Simpasai, bahkan ada yang menggunakan senjata tajam seperti, parang, kapak, panah, dan senapan angin. Ketegangan yang terjadi antar warga dua kelurahan ini terjadi pada sabtu sore, dengan membawa berbagai senjata tajam, kedua kubu berkumpul di jalan raya yang mengakibatkan lalu lintas lumpuh. Jalan kembali bisa dilintasi setelah polisi turun ke lokasi (liputan6.com).

Konflik yang berlangsung secara massif yang desertai dengan tindakan pengrusakan mengakibatkan jatuhnya korban jiwa. Imbas kerusakan fasilitas publik, rumah warga yang berada dekat lokasi dan mobil yang diparkir pinggir jalan mengalami kerusakan cukup parah serta korban yang mengalami luka luka harus dibawah kerumah sakit dan puskesmas terdekat. Satu kompi BRIMOB diturunkan dilokasi untuk mencegah bertambahnya korban serta menghentikan konflik tersebut. Sehingga konflik dapat direda, walaupun ketegangan antara kedua kelurahan masih ada (Dompubicara.com). 
Selang beberapa hari konflik kembali terjadi, dengan lokasi yang berbeda yaitu area persawahan. Area persawahan Doro Cumpa berubah menjadi medan pertempuran warga kelurahan Kandai Dua dan warga kelurahan Simpasai, mereka mempersenjatai diri dengan senapan rakitan, parang, serta busur panah dan anak panah. Sabtu (24/5/2014), “dilokasi tersebut salah seorang warga Lingkungan Ncera, Kelurahan Simpasai meninggal dunia dengan luka tembak senjata api rakitan dan sabetan senjata tajam" (liputan6.com, Dompu).

Melihat fenomena konflik antara kelurahan Kandai Dua dengan kelurahan Simpasai, tentunya sangat memberikan dampak terhadap kehidupan sosial masyarakat. Partisipasi masyarakat pun sangat diperlukan dalam upaya memberikan sumbangan gagasan mengenai solusi yang dapat diterapkan karena masyarakatlah yang melihat, merasakan dan memahami langsung dampak dari adanya fenomena konflik ini. Pertisipasi masyarakat ini hanya punya makna jika disertai dengan perasaan tanggung jawab. Berbagai pertimbangan sangat mungkin terjadi dalam benak masyarakat, apa yang diterima, dilihat dan dirasakan akan mempengaruhi pengetahuan masyarakat terkait subjek dan objek dari konflik. Disinilah akan muncul upaya resolusi yang dilakukan oleh berbagai pihak akan mencapai hasil yang baik sesuai dengan harapan berbagai pihak

Penelitian Lisdayanti (2016), terdapat perbedaan dengan yang dirumuskan oleh penulis. Perbedaan terlihat dari fokos penelitiannya mengenai faktor yang menyebabkan terjadinya tawuran antar warga di kelurahan Rappojawa, Makassar. Sedangkan dalam penelitian yang dilakukan oleh penulis, pembahasan mengenai konflik lebih difokuskan pada konstruksi masyarakat, baik yang terlibat secara langsung maupun yang merasakan dampak dari konflik yang terjadi. Dalam penelitian yang dilakukan oleh Lisdayanty, sejauh ini belum ada pembahasan yang dikaji terkait dengan fokus permasalahan dari penelitian yang dilakukan oleh penulis sebagaimana yang telah disebutkan.

Berbeda dengan penelitian yang dilakukan oleh Muhammad Iskandar (2013) yang membahas tentang adanya perbedaan pandangan dan ketidakadilan antara pengurus dan anggota parkir, mengenai pengelolaan parkir yang mengakibatkat terjadinya konflik. Sedangkan pada penelitian yang dilakukan oleh 
penulis membahas mengenai konstruksi masyarakat terhadap konflik yang berada dikawasan terjadinya konflik, yang merasakan ketegangan dari situasi konflik, dan yang ikut terlibat secara aktif dalam konflik tersebut.

Sedangkan penelitian yang dilakukan oleh sahlan (2015), Perbedaan penelitiannya dengan penelitian yang dilaksanaan oleh penulis dapat dilihat dari segi tujuan, karena metode yang digunakan sama yakni kualitatif deskriptif namun yang membedakannya adalah ditujuan yakni penelitian bertujuan untuk mengetahui faktor-faktor apa yang melatarbelakangi terjadinya konflik di Kecamatan Lambu kabupaten bima, dan faktor-faktor yang melatarbelakangi meluasnya eskalasi konflik di kecamatan Lambu kabupaten bima. Sedangkan pada penelitian yang dilakukan oleh penulis bertujuan untuk mengetahui konstruksi konflik di masyarakat Kecematan Woja Kabupaten Dompu.

Penelitian yang dilakukan oleh Rindra Sulistiyono (2013) bertujuan untuk mengetahui persepsi masyarakat terhadap konflik yang melibatkan oknum Perguruan Pencak Silat di Kabupaten Madiun, dan untuk mengetahui dampakdampak yang ditimbulkan dari adanya konflik yang melibatkan oknum Perguruan Pencak Silat di Kabupaten Madiun. Sedangkan pada penelitian yang dilaksanakan oleh penulis bertujuan untuk mengetahui konstruksi masyarakat terhadap konflik sosial di Kecamatan Woja Kabupaten Dompu dan untuk memahami resolusi konflik yang terjadi di Kecamatan Woja Kabupaten Dompu. Dimana konflik yang dimaksud adalah konflik antar kampung yang terjadi di Kecamatan Woja Kabupaten Dompu.

Setiap masyarakat pasti pernah mengalami konflik, baik konflik dalam cakupan kecil atau konflik berskala besar. Konflik yang cakupannya kecil, seperti konflik dalam keluarga, teman, dan atasan/bawahan. Sementara itu, konflik dalam cakupan besar, seperti konflik antar golongan atau antarkampung. Menurut Soekanto, konflik adalah suatu proses sosial dimana individu atau kelompok berusaha untuk memenuhi tujuannya dengan jalan menentang pihak lawan dengan disertai ancaman dan kekerasan. 
Menurut Johan Galtung, konflik dapat terjadi karena berbagai individu, kelompok, dan organisasi membawa angka kepentingannya masing-masing. Kepentingan tersebut bisa berwujud kepentingan ekonomis maupun politis. Dua kelompok sosial dengan kepentingan tertentu berada dalam satu lingkungan yang sama, masing-masing menciptakan persepsi terhadap kepentingan kelompok di luarnya. Proses ini sendiri nantinya akan membawa pada bentuk perilaku-perilaku tertentu yang menciptakan kontradiksi dan situasi ketegangan.

Galtung juga memperkenalkan konsep segitiga konflik dalam menganalisis terciptanya sebuah konflik. Analisis yang dimaksud disini adalah analisis hubungan sebab akibat atau interaksi yang memungkinkan munculnya sebuah konflik sosial. Dalam konsep segitiga konflik Galtung terdapat 3 dimensi dimana antara satu sama lain saling terikat. 3 dimensi tersebut adalah dimensi sikap, dimensi perilaku, serta dimensi kontradiksi.

Pertama, Dimensi sikap adalah persepsi dari anggota etnis atau kelompok tentang isu-isu tertentu yang ada kaitannya dengan etnis atau kelompok lain. Sederhananya sikap atau persepsi dipicu oleh beragam hal yang berkaitan dengan kelompok lain. Kedua, Dimensi perilaku merupakan sebuah bentuk kerja sama, persaingan atau bisa juga permusuhan. Perilaku disini terbentuk dari adanya persepsi dari anggota kelompok terhadap kelompok lain yang dimanifestasikan kedalam sebuah tindakan nyata. Ketiga, Dimensi kontradiksi adalah kemunculan situasi yang di dalam prosesnya melibatkan unsur sikap dan perilaku. Secara sederhana kontradiksi dapat tercipta karena adanya unsur persepsi dan tindakan nyata dari kelompok-kelompok yang hidup dalam lingkungan sosial. Pada dasarnya, dalam konsep segitiga konflik Galtung, sikap melahirkan perilaku, dan pada saatnya melahirkan apa yang dinamakan kontradiksi atau situasi yang kurang baik.

Secara sederhana pengertian konflik adalah saling memukul (configere). Namun, konflik tidak hanya berwujud pada pertentangan fisik. Secara umum, pengertian konflik sosial (pertentangan) adalah sebagai suatu proses sosial antara dua pihak atau lebih ketika pihak yang satu berusaha menyingkirkan pihak lain dengan cara menghacurkan atau membuatnya tak berdaya. Konflik merupakan situasi yang wajar dalam setiap masyarakat. Bahkan tidak ada satu masyarakat pun 
yang tidak pernah mengalami konflik. Ibnu khaldun memperlihatkan bagaimana dinamika konflik dalam sejarah manusia sesungguhnya ditentukan oleh keberadaan kelompok sosial (ashobiyah) berbasis pada identitas, golongan, etnis, maupun tribal. Kelompok sosial dalam struktur sosial mana pun dalam masyarakat dunia memberi konstribusi terhadap berbagai konflik. Hal ini dipengaruhi oleh sifat asal manusia yang sama dengan hewan. Nafsu adalah kekuatan hewani yang mampu mendorong berbagai kelompok sosial menciptakan berbagai gerakan untuk memenangi (to win) dan menguasai (to rule) (Susan, 2014).

\section{Metode Penelitian}

Penelitian ini dilakukan di Kelurahan Kandai Dua Kecamatan Woja Kabupaten Dompu. Penelitian ini menggunakan metode kualitatif, guna memahami fenomena yang dialami subjek penelitian dengan cara mendeskripsikan dalam bentuk kata- kata, bahasa, pada suatu konteks khususnya yang alamiah.

Data yang dipergunakan dalam penelitian ini adalah data primer dan data sekunder. Data primer yaitu sumber data yang diambil peneliti melalui wawancara dan observasi. Adapun data primer dalam penelitian ini adalah individu-individu yang terlibat secara langsung maupun yang ikut merasakan akibat situasi konflik sosial di kecamatan Woja. Sedangkan data sekunder berdasarkan buku, jurnal, pemberitaan online maupun cetak yang mendukung penelitian dan dipergunakan oleh peneliti. dan data sekunder merupakan sumber yang tidak langsung memberikan data kepada pengumpul data, misalnya lewat orang lain atau lewat dokumen. Data yang diperoleh melalui beberapa informasi antara lain melalui: pertama, Dokumen seperti data yang diperoleh dari instansi/lembaga pemerintah yang terkait dengan penelitian. Kedua, penelitian terdahulu terkait tema penelitian.

Pengumpulan data dilakukan dengan wawancara mendalam kepada masyarakat yang mengalami konflik di desa Kandai Dua. Adapun pemilihan informannya menggunakan teknik purposive sampling yang berjumlah 8 orang. Peneliti melakukan observasi untuk mendapatkan informasi terkait tindakan social masyarakat yang memicu terjadinya konflik antar kelurahan. Obrservasi dilakukan 
pada kedua desa yaitu desa Kandai Dua dan Desa Simpasai yang sering berkonflik. Pengumpulan data yang terakhir melalui dokumentasi yakni dilakukan untuk mendukung hasil wawancara dan juga observasi yang dilakukan oleh peneliti melalui foto, video yang berkaitan dengan kegiatan masyarakatat Kandai Dua yang mengarah ataupun yang memicu terjadi konflik.

Adapun sumber data yang digali dalam penelitian melalui ini informan sebagai berikut Informan pertama penulis pilih langsung dengan beberapa pertimbangan yang dirasa sangat cocok dengan penelitian yang penulis angkat. Informan pertama penulis yaitu Din. Din merupakan seorang petani yang berusia 34 tahun yang bertempat tinggal di lingkungan Kandai Dua Barat. Selain, berprofesi sebagai petani ia juga aktif di berbagai organisasi, seperti organisasi pengadaan bibit tanaman pangan, pemberdayaan masyarakat, dan juga organisasi kepemudaan. Kemudian informan kedua adalah Aba. Aba merupakan soerang pelajar yang berusia 19 tahun yang bertempat tinggal di lingkungan Kandai Dua Tmur RT 04. Setiap kali ada peperangan antar kampung. Informan Aba pasti ikut ambil bagian untuk mempertahankan wilayah tempat tinggalnya. Informan Aba pernah mengalami luka parah akibat terkena oleh senjata tajam yaitu panah pada bagian matanya.

Selanjutnya penulis melakukan wawancara dengan informan Ketiga Ami. Ami Merupakan seorang petani yang berumur 26 tahun dan bertempat tinggal di lingkungan Kandai Dua Tmur. Informan Ami juga selalu aktif dalam mempertahakan wilayah tempat tinggalnya. Apabila dia mendapatkan perlakuan yang merugikan baik dirinya maupun warga Kandai Dua. Dia akan mengumpulkan anggota untuk segera mengambil tindakan dengan melakukan pemblokiran jalan utama yang menuju Pasar Atas Dompu. Ami merekomendasikan beberapa nama untuk selanjutnya dijadikan informan penulis, termasuk didalamnya informan keempat Bapak Fer selaku tokoh masyarakat di Kandai Dua Timur. Fer merupakan pekerja PNS yang berumur 43 tahun tinggal di lingkungan Kandai Dua Tmur. Selain profesinya sebagai PNS, ia juga aktif di organisasi bentukan pemerintah untuk menangani sumber-sumber konflik. 
Selanjutnya oleh penulis melakukan wawancara pada infoman kelima adalah Bapak Eno. Bapak Eno berumur 39 tahun berprofesi sebagai petani dan bertempat tinggal di lingkungan Kandai Dua Barat. Bapak Eno juga merupakan tokoh masyarakat di Kandai Dua Barat. Sedangkan informan keenam pak Gen merupakan salah satu tokoh masyarakat yang sangat dihormati di lingkungan Kandai Dua Tmur. Informan Pak Gen berusia 57 tahun berprofesi sebagai pegawai Swasta

Terakhir penulis melakukan wawancara dengan informan ketujuh Baba. Baba berprofesi sebagai pelajar yang berusia 21 tahun bertempat tinggal di lingkungan Kandai Dua Timur. Dia pernah menusuk musuhnya dengan belati memotong tangan warga kampung lain dengan parang. Sehingga orang tuanya harus memindahkanya untuk sekolah diluar daerah.

\section{Hasil dan Pembahasan}

Berdasarkan hasil pengamatan dan observasi yang dilakukan, penulis melihat para pemuda atau remaja terbagi dalam kelompok-kelompok atau gang. Kelompok-kelompok atau gang remaja pada waktu sore dan malam hari seringkali duduk di pinggir jalan depan toko, bengkel, dan di halte depan Dinas Perhubungan Kabupaten Dompu. Selain itu, pemuda juga seringkali bergadang pada acara resepsi pernikahan yang diselenggarakan masyarakat. Acara hiburan yang diselenggarakan oleh keluarga pasangan pengantin seringkali mengundang/menyelenggarakan hiburan dengan orgen tunggal sampai larut malam. Disini pula remaja dari berbagai kampung sering berkumpul dan semua berjoget bersama sampai menjelang subuh. Tetapi sebelum mereka joget terlebih dahulu mereka minum minuman keras, sehingga pada saat joget bila disenggol sedikit saja oleh kelompok lain langsung ribut dan baku hantam bahkan sampai menusuk lawannya dengan belati.

Selain dari remaja, ada pula sekelompok preman baik dari Kelurahan Kandai Dua maupun dari Kelurahan Simpasai yang sengaja melakukan tindakan provokasi, konflik pun tidak dapat dihindari dan kembali terjadi. Pada kasus konflik yang terjadi tahun 2014, beberapa preman dari Kelurahan Kandai Dua dengan 
Kelurahan Simpasai saling teleponan mengajak untuk turun medan pertempuran atau berperang dengan menggunakan berbagai senjata tajam seperti parang, tombak, panah kawat dan senjata api rakitan. Lokasi yang dijadikan tempat bertemunya kedua kelurahan yang bertikai tersebut yaitu persawahan warga di Doro Cumpa. Sehingga suasana di persawahan warga Doro Cumpa begitu ramai, baik diramaikan oleh yang terlibat konflik langsung maupun yang hanya ikut menjadi penonton.

Konflik yang terjadi di Kecamatan Woja antara warga masyarakat Kelurahan Kandai Dua dengan warga masyarakat Kelurahan Simpasai sebenarnya dilatarbelakangai oleh beberapa faktor. Pertama, kenakalan remaja merupakan gejala patologis sosial pada remaja yang disebabkan oleh suatu bentuk pengabaian sosial yang pada akhirnya menyebabkan perilaku menyimpang. Kenakalan remaja meliputi semua perilaku yang menyimpang dari norma-norma dalam masyarakat, pelanggaran status, maupun pelanggaran terhadap hukum pidana. Hal itu terjadi karena remaja belum bisa mengendalikan emosinya dengan stabil.

Seperti yang terjadi Pada malam takbiran Idul Adha beberapa anak remaja melakukan pemanahan terhadap anak dari kampung Rasa Na'e. Sehingga anak remaja kampung Rasa Na'e mengalami luka serius dan harus dibawah ke Rumah Sakit Umum Daerah Dompu (RSUD). Setelah dilakukan penyelidikan terhadap kasus pemanahan yang dilakukan tersebut. Para pelaku yang melakukan tindakan pemanahan terhadap anak remaja dari kampung Rasa $\mathrm{Na}$ 'e ada sekitar sepuluh orang. Salah satu pelaku yang melakukan tindakan pemanahan terhadap anak remaja kampung Rasa Na'e ditangkap oleh pihak keamanan di rumahnya Lingkungan Kandai Dua Timur. Pelaku berhasil di tangkap karena saksi mata yang berada di lokasi kejadian mengenal ciri-ciri pelaku yang melakukan aksi pemanahan tersebut. Setelah pihak keamanan melakukan penyelidikan lebih lanjut. Para pelaku berjumlah sekitar orang yang dimana salah satu pelaku merupakan anak dari salah satu pihak kepolisian. Para pelaku melakukan aksi tersebut sebagai balasan karena beberapa hari sebelumnya salah seorang dari teman mereka di panah oleh pihak korban. Mereka pun tidak terima dan akhirnya mereka melakukan aksi pembalasan. 
Kedua, dendam lama diamana konflik yang terjadi antara kelurahan Kandai Dua dengan kelurahan Simpasai sebenarnya dari jaman dulu, sejak terbentuknya masyarakat trasmigran Lingkungan Renda Keluran Simpasai. Kedua kelurahan ini selalu mengalami pertikaian dari masa ke masa. Kelurahan Kandai Dua dengan kelurahan Simpasai tidak bisa bertemu dalam satu situasi ketengangan seperti ajang pertandingan karena gengsi mempertahankan nama kampung. Sedikit saja kesalapahaman antara kedua kelurahan maka konflik akan terjadi. Ketiga, hukum yang lemah. Hukum merupakan seperangkat aturan atau norma-norma yang mengatur kehidupan masyarakat dan bersifat memaksa yang apabila dilanggar akan mendapatkan hukuman (sanksi). Implementasi hukun yang lemah berdampak pada terjadinya berbagai tindakan yang tidak terkendali.

Konflik yang biasa terjadi di lingkungan masyarakat baik masyarakat kelurahan Kandai Dua maupun kelurahan Simpasai akibat dari hampir tidak adanya hukum yang mengontrol dan yang dapat memberikan efek terhadap pelaku yang terlibat dalam proses awal terjadinya konflik.

Selain itu, Pemahaman masyarakat terkait dengan Hak Asasi Manusia (HAM) juga merupakan salah satu penyebab terjadinya konflik. Dalam implementasinya dilapangan terlalu berlebihan, masyarakat memahaminya hanya sebatas pada hak tetapi lupa akan kewajiban. Begitu pula pada kasus yang menimpa para remaja. Semenjak keluarnya undang-undang perlindungan anak pada tahun 2002, para pemuda remaja merasa bebas tampa adanya batas. Pemahaman yang salah dan implementasi yang berlebihan inilah yang menjadi pemicu konflik.

Seperti ketika ada warga masyarakat yang menegur terhadap tindakan yang dilakukan oleh anak remaja seperti minum-minuman keras. Beberapa anak remaja akan membalas untuk tidak mengurusi kehidupan orang lain, urus saja urusan dan kehidupan sendiri. Apabila salah satu warga masyarakat memukul dengan maksud untuk memberikan teguran supaya mereka sadar, malahan akan dilaporkan dan dituntut ke polisi. Keempat, Perbedaan Kepentingan. Perbedaan merupakan hal yang senantiasa ada dalam kehidupan sosial masyarakat, baik perbedaan antara individu atau kelompok dengan individu atau kelompok lainnya, begitu pula dengan 
perbedaan kepentingan. Biasanya konflik yang terjadi didasari oleh beberapa oknum preman. Mereka sengaja membuat atau menciptakan konflik antara Kelurahan Kandai Dua dengan Kelurahan Simpasai. Ketika mereka dapat membuat atau menciptakan konflik, nama beberapa oknum tersebut menjadi semakin tenar dan terkenal.

Mereka akan mendapatkan kekuasan dengan membuat orang lain takut pada mereka. Oknum-oknum ini akan meminta atau menarik pajak keamanan di lembaga atau instansi pemerintah. Selain itu, ketika ada proyek-proyek besar seperti pembangunan jalan, jembatan, bendungan dan beberapa sanitasi masyarakat lainnya. Mereka akan mendapat bagian karena memang mereka akan di panggil oleh kontraktor sebagai sesi keamanan agar proyek dapat berjalan lancar tampa ada gangguan dari pihak-pihak lain. Jika dilihat dari latar belakang kedua kelurahan yang bertikain ini. Kelurahan Kandai Dua merupakan penduduk asli dari Kabupaten Dompu, sedangkan beberapa desa merupakan trasmingaran lokal yang berasal dari Kabupaten Bima. Seperti Kelurahan Montabaru, kelurahan Simpasai dan Desa wawonduru. Sehingga untuk penguasaan lahan sendiri paling banyak adalah warga Kelurahan Kandai Dua, karena memang warga kelelurahan Kandai Dua merupakan tuan tanah. Sedangkan untuk Kelurahan Simpasai kususnya warga Lingkungan Renda pada awalnya hanya bekerja sebagai buruh seperti, buruh tani dan pembuat batu bata. Namun semakin lama lingkungan renda dapat melakukan penyesuaian sehingga beberapa warga lingkungan renda sudah memiliki lahan untuk digarap sendiri.

Dalam kasus pertandingan atau turnamen seperti turnamen bola voli, bulu tangkis dan sepak bola. Apabila atmosfer permainan mulai memanas sehingga situasi menjadi semakin tegang akhirnya bukan bola lagi yang akan dikejar melainkan kaki dari para pemain. Sehinnga konflik pun terjadi. Seperti yang pernah terjadi kekitar tahun 2001, yang dimana konflik berawal dari pertandingan sepak bola antara Kelurahan Kandai Dua dengan Kelurahan Montabaru berakhir ricuh diwarnai aksi pelemparan batu dan senjata tajam seperti parang. Akibat dari kejadian tersebut salah satu warga Kelurahan Kandai Dua meninggal dunia. 
Pada tahun 2014, konflik yang terjadi sampai kembali harus memakan korban jiwa yang dimana salah seorang warga kelurahan Simpasai meninggal dunia. Konflik juga disertai dengan aksi pembakaran rumah warga sehingga puluhan perempuan dan anak-anak diungsikan ke sejumlah tempat yang lebih aman. Setidaknya 17 warga dari kelurahan Kandai Dua dan Kelurahan Simpasai ditangkap polisi dengan sejumlah barang bukti yang disita dari rumah mereka, yakni ratusan senjata tajam, seperti tombak, panah kawat, dan parang

Gambar 1. Kondisi Konflik Kelurahan Kandai Dua Tahun 2014

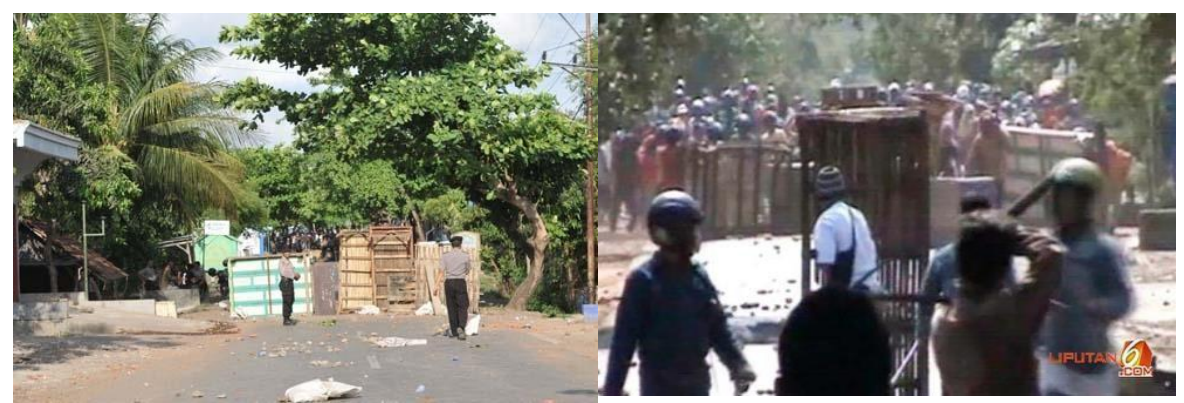

Menurut teori segitiga konflik (the conflict triangle) galtung,ada baiknya konflik dilihat sebagai sebuah segitiga dengan tiga komponen yang terdiri dari sikap, perilaku, dan kontradiksi. Sikap mengacu kepada pemahaman atau kesalahapahaman terhadap kelompok sendiri dan kelompok lawan, dan sikap ini bisa bersifat positif dan negatif. Sikap seringkali dipengaruhi oleh perasaan seperti ketakutan, kemarahan, dendam, dan rasa tidak suka. Perilaku sebagai salah satu komponen dari segitiga konflik mencakup kerja sama dan koersi, sekumpulan gerakan, tampilan, dan tindakan yang menunjukan keariban dan permusuhan. Kontradiksi tidak lain adalah situasi konflik yang fundamental sifatnya, termaksud ketidaksesuaian tujuan masing-masing pihak, baik itu ketidaksesuaian yang benarbenar aktual atau sekedar perbedaan yang ditarik dari kesan sepintas.

Jika dilihat dari dimensi sikap informan sebagaimana yang peneliti dapat dari beberapa informan, meraka menunjukan sikap tidak suka, tidak terima, marah dan akhirnya dendam ketika warga Kandai Dua mendapatkan perlakuan yang tidak menyenangkan dari warga Lingkungan Renda Kelurahan Simpasai. Sebagai respon perlakuan yang tidak menyenangkan tersebut dapat dilihat perilaku apa yang akan 
diambil oleh beberapa pemuda Kandai Dua. Para pemuda Kandai Dua juga melakukan pemblokiran jalan sehinga jalan lintas sumbawa tadak bisa diakses akibatnnya merugikan berbagai pihak.

Dimensi terakhir yaitu dimensi kontradiksi dimana kemunculan situasi yang melibatkan problem sikap dan perilaku. Antara Kedua kelurahan yaitu Kelurahan Kandai Dua dan Kelurahan Simpasai saling melakukan aksi pemblokiran jalan di perbatasan kedua kelurahan. Tempat tersebut menjadi tempat saling melempari batu, dan berbagai senjata tajam. Pemblokiran jalan sekaligus menjadi benteng pertahanan agar warga kelurahan Simpasai tidak bisa masuk dikelurahan Kandai Dua begitupun sebaliknya. Ada rasa bangga dan puas ketika mereka mampu mempertahankan wilayah tempat tinggal masing-masing dari serangan yang dilancarkan, baik itu dari kelurahan Kandai Dua maupun dari kelurahan Simpasai.

Adapun usaha-usaha penyelesaian atau resolusi konflik yang dilakukan pemerintah daerah maupun oleh beberapa tokoh masyarakat dari kedua kelurahan dan pemerintah Kabupaten Dompu antara lain:

Negosiasi. Proses negosiasi pernah dilakukan oleh pihak kelurahan, yaitu pak lurah Kandai Dua dan ibu lurah dari kelurahan simpasai serta 7 tokoh masyarakat dari kedua kelurahan. Proses ini tidak berjalan dengan lancar karena pada saat negosiasi, situasi tegang dan sedikit memanas. Beberapa pihak menolak permintaan yang dilontarkan baik dari Kelurahan Kandai Dua maupun dari Kelurahan Simpasai. Selain itu, Ibu Lurah tidak bisa mengambil keputusan dengan bijak karena adanya intervensi dari beberapa pihak yang emosi pada saat proses negosiasi terjadi. Sehingga negosiasi berakhir dengan buntu. Akibat dari proses negosiasi yang tidak menghasilkan atau menemui kesepakatan itu. Akhirnya kedua kelurahan menginginkan supaya Pemerintah Daerah Kabupaten Dompu dalam hal ini Bupati untuk turun tangan langsung guna mendamaikan kedua kelurahan yang bertikai.

Konsiliasi. Upaya penenganan konflik dengan cara konsiliasi pernah dilakukan akan tetapi gagal kerena salah satu pihak tidak terima dengan adanya proses pendamaian tersebut. Hal ini dikarenakan salah satu warga dari kelurahan simpasai meninggal dunia. Lembaga yang berperan dalam upaya mendamaikan 
kedua kelurahan ini adalah lembaga hukun. Dimana proses pendamain dilakukan di KODIM Kabupaten Dompu. Mediasi, Pihak kepolisian mencoba melakukan mediasi dengan mempertemukan kedua kelurahan yang bertikai, dimana pada saat itu dihadiri oleh lurah dari kedua kelurahan dan 7 tokoh masyarakat untuk melakukan perundingan dan negosiasi. Namun, tidak mendapatkan hasil yang memuaskan untuk kedua belah pihak yang berkonflik sehingga proses mediasi gagal. Tetapi tidak berhenti sampai disitu, pemerintah bekerja sama dengan masyarakat membentuk sebuah organisasi kewapadaan dini KecamatanWoja. Dimana yang menjadi ketua adalah selaku tokoh masyarakat keluruhan Kandai Dua Timur. Organisasi kewaspadaan dini merupakan bentukan dari BAKESBANG POLDAGRI KabupatenDompu sebagai upaya untuk meminimalisir terjadinya konflik dikemudian hari.

Salah satu langkah yang dilakukan oleh organisasi kewaspadaan dini adalah mencari, mengumpulkan, mengoordinasikan dan mengomunikasikan data serta informasi atau bahan keterangan dari fokus kewaspadaan dini masyarakat di KecamatanWoja dan berbagai sumber lainnya mengenai potensi, gejala, atau peristiwa timbulnya ancaman, tantangan, hambatan dan gangguan di KecamatanWoja serta melakukan sosialisasi pembinaan dan mengumpulkan data setiap kondisi yang dapat menyebabkan potensi terjadinya konflik sosial yang mengarah kepada konflik komunal. Arbitrasi, Proses arbitrasi dinilai terlalu lambat dilakukan, arbitrasi tidak dilakukan sedari awal sebelum konflik itu berujung pada kekerasan dan terjadinya pengerusakan serta jatuhnya korban jiwa, melainkan baru dilakukan setelah puncak dari konflik yang menewaskan salah seorang warga kelurahan Simpasai dan pengerusakan rumah orang Kandai Dua yang bertempat tinggal dikelurahan lain dan di balas dengan warga Kandai Dua dengan pembakaran rumah warga Rendah yang bertempat tinggal di Desa Bolonduru.

Dari apa yang kita lihat penanganan konflik dengan penyaluran tenaga Kepolisian, BRIMOB, TNI, dan Pihak-pihak keamanan lainya "diklaim" sebagai langkah utama dalam menangani konflik. Tindakan pihak kepolisian lebih cenderung menekankan pada permasalahan hukum dan bertindak menyelesaikan masalah ketika 
tengah bersifat destruktif (menghancurkan). Pola penyelesaian masalah yang seperti itu, kecenderungan mengabaikan karakteristik budaya, latarbelakang sosial, dan permasalahan-permasalahan yang bersifat laten lainya

\section{Kesimpulan}

Konflik yang terjadi di KecamatanWoja Kabupaten Dompu antara warga masyarakat kelurahan Kandai Dua dengan warga masyarakat kelurahan Simpasai ternyata dilatarbelakangi oleh berbagai faktor berikut ini: kenakalan remaja; dendam; hukum yanh lemah; adanya perbedaan kepentingan antara warga masyarakat kelurahan Kandai Dua dengan warga masyarakat kelurahan Simpasai. Terdapat beberapa langkah atau upayaresolusi konflik yang dilakukan baik oleh pemerintah daerah maupun oleh tokoh masyarakat antara kedua kelurahan, yaitu antara lain: negosiasi, konsiliasi, mediasi, dan terakhir arbitrasi

Peristiwa ataupun kasus konflik yang terjadi di KecamatanWoja telah memberikan pelajaran berharga bagi kita semua, khususya bagi warga masyarakat Kelurahan Kandai Dua dan masyarakat Kelurahan Simpasai dan di sekitarnya. Peran pemerintah daerah dan tokoh masyarakat tentu sangat diperlukan dalam upaya untuk mengurangi konflik-konflik yang akan terjadi agar tidak terus berlannjut dan kembali memakan korban jiwa. Selain itu, perlu kerjasama dengan masyarakat sehingga sumber-sumber konflik dapat diminimalisir dan dicarikan solusi terbaik.

\section{Daftar Pustaka}

Afrizal. 2015. Metode Penelitian kualitatif: Sebuah Upaya Mendukung Penggunaan Penelitian Kualitatif Dalam Begbagai Disiplin Ilmu. Jakarta: Rajawali Pres.

Basrowi dan Suwandi. 2008. Memahami Penelitian Kualitatif. Jakarta: Rineka Cipta

Bungin, Burhan. 2015. Konstruksi Sosial Media Massa: Kekuatan Pengangaruh Media Massa, Iklan Televisi, dan Keputusan Konsumen Serta Kritik Terhadap Peter L. Berger dan Thomas Luckmann. Jakarta: Prenadamedia Group. 
Fisher, Simon, dkk. 2001. Mengelola Konflik : Keterampilan dan Strategi Untuk Bertindak, Cetakan Pertama, Alih Bahasa S.N. Kartikasari, dkk, The British Counsil, Indonesia, Jakarta

https://kambalidompumantoi.wordpress.com/2015/05/06/suku-mbojo-adalah-sukudi-kabupaten-dompu-bukan-suku-samawa-sumbawa/

http://m.republika.co.id/amp/p1wr4g368

http://nasional.tempo.co/real/457121/kontras-konflik-sumbawa-liberalisasikerusuhan

http://nasional.tempo.co/amp/794818/lagi-dua-desa-di-dompu-bentrok-dan-lemparipolisi\#aoh=15740422962681\&referrer=https\%3A\%2F\%2Fwww.google.co m\&amp_tf=Dari\%20\%251\%24s

https://www.liputan6.com/news/read/468874/video-warga-dari-2-desa-bertikai-didompu

https://www.bimakini.com/2012/11/bupati-minta-warga-yang-bertikai-menahandiri/

https://www.kompasiana.com/ranggababuju/552a04d2f17e61db49d62403/bimatanah-yang-tersulut-menyelesaikan-konflik-dengan-konflik

http://prof-mahsun.com/ konflik dan akar penyebabnya pengamatan awal terhadap potensi konflik di nusa tenggara baratIskandar, Muhammad. 2013. konflik masyarakat dusun daengan, maguwoharjo, depok, sleman. Diakses dari digilib.uin-suka.ac.id/.../1bab\%201\%2c\%20daftar\%20pustaka.pdf

http://rri.co.id/post/berita/471442/sigap_polri/tahun_2017_ntb_keluar_dari_zona_m erah_konflik_sosial.html.

Lisdayanty. 2016. Studi Tentang Tawuran Antar Warga di Kelurahan Rappojawa Kecamatan Tallo. diakses dari ojs.unm.ac.id/tomalebbi/article/download/303/1640

Moleong, Lexy J. 2017. Metodologi Penelitian Kualitatif. Ed. Revisi. Bandung: PT. Remaja Rosdakarya

Murdiyatmoko, Janu 2007. Sosiologi Memahami dan Mengkaji masyarakat. Grafindo Media Pertama: Bandung

Nasikun. 1993. Sistem Sosial Indonesia, Jakarta: PT RajaGrafindo Persada

Ritzer, George. 2014. Sosiologi Ilmu Pengetahuan Berparadigma Ganda.Jakarta: Rajawali Pers.

Ritzer, George. 2014. Teori Sosiologi Modern. Terjemahan Tri Wibowo. Jakarta: Kencana.

Sahlan. 2015. Konflik Antara Masyarakat Dengan Pemerintah (Studi Kasus Pada Oksplorasi Tambang di Kecamatan Lambu Kabupaten Bima Nusa Tenggara Barat)

Sugiyono. 2016. Memahami Penelitian Kualitatif. Bandung: Alfabeta.

Susan, Novri. 2014. Pengantar sosiologi konflik. Jakarta: Prenadamedia Group. Sutopo, H.B. 1996: Metodologi Penelitian Kualitatif. Surakarta: Jurusan Seni Rupa Fakultas Sastra UNS.

www.dompukab.go.id/wp-content/uploads/2018/11/DDA-Dompu-2017.pdf. diakses tanggal 21 Mei 2019 jam 12:52 